\title{
PENETAPAN PARAMETER STANDARDISASI NON SPESIFIK DAN SPESIFIK EKSTRAK DAUN PACAR KUKU (Lawsonia inermis L.)
}

\section{DETERMINATION OF NON SPECIFIC AND SPECIFIC STANDARDIZATION PARAMETER OF HENNA (Lawsonia inermis L.) LEAVES EXTRACT}

\author{
Zainab, Nanik Sulistyani, Anisaningrum \\ Fakultas Farmasi Universitas Ahmad Dahlan \\ Email: zzanisa@gmail.com
}

\begin{abstract}
ABSTRAK
Standardisasi ekstrak tumbuhan obat di Indonesia merupakan salah satu tahapan penting dalam pengembangan obat asli Indonesia. Daun pacar kuku (Lawsonia inermis L.) merupakan salah satu tanaman yang mengandung senyawa naftokuinon dengan berbagai aktivitas. Penelitian ini bertujuan untuk melakukan standardisasi ekstrak daun pacar kuku sehingga diharapkan dapat digunakan sebagai acuan parameter standar mutu ekstrak karena standarisasi ekstrak pacar kuku belum tercantum di MMI dan FHI. Dalam penelitian ini penyarian ekstrak daun pacar kuku dilakukan menggunakan metode infundasi. Penetapan parameter non spesifik meliputi kadar air, kadar abu total, kadar abu tidak larut asam dan cemaran mikroba dengan metode ALT. Penetapan parameter spesifik yaitu dengan mengetahui organoleptis ekstrak, profil KLT dan menetapkan kadar naftokuinon total menggunakan metode kromatografi lapis Tipis (KLT) dengan fase diam silika gel $60 \mathrm{~F}_{254}$, fase gerak metanol : kloroform (2:8) dan analisis kuantitatif menggunakan densitometri pada panjang gelombang maksimal. Hasil standardisasi untuk parameter non spesifik menunjukkan kadar air $(7,33 \pm 0,52 \%$ v/b), kadar abu total $(6,43 \pm 0,25 \%)$, kadar abu tidak larut asam $(0,106 \pm 0,004 \%)$, dan uji cemaran mikroba $\left(85 \times 10^{2} \mathrm{CFU} / \mathrm{g}\right)$. Hasil untuk parameter spesifik menunjukkan organoleptis ekstrak (kental, warna coklat tua, rasa agak pahit dan berbau khas daun pacar kuku), dengan kandungan senyawa naftokuinon, kumarin, flavonoid, polifenol, alkaloid, dan kadar naftokuinon total $(7,43 \pm 0,28 \%)$. Ekstrak daun pacar kuku sudah memenuhi persyaratan sesuai acuan standar Farmakope Herbal Indonesia tentang syarat ekstrak sebagai bahan baku sediaan obat tradisional.
\end{abstract}

Kata kunci : Ekstrak, pacar kuku (Lawsonia inermis L.), parameter non spesifik, parameter spesifik

\section{ABSTRACT}

Standardization of extracts of medicinal plants in Indonesia is one of the important stages in the development of original drugs Indonesia. Leaves of henna (Lawsonia inermis L.) is one of the plants that contain of naphthoquinone 
compounds with various activities. In this research, the lack of standardization of the extracts of leaves of henna. Because in this case, the raw material crude drugs and extracts of henna leaves is not listed in the monograph official publication of the Ministry of Health (Materia Medika Indonesia and medicinal plant extract Monograph). Therefore, it is expected to do the determination of standardizing parameters henna leaves extract can be used as a reference as a parameter extracts quality standards. In this research henna leaf extract made with infundation method. Determination of non-specific parameters includes moisture content, total ash, acid insoluble ash content and microbial contamination with ALT method. Determination of specific parameters by organoleptic extract, TLC profile and naphthoquinone content using thin layer chromatography (TLC) with the stationary phase silica gel $60 \mathrm{F254}$, the mobile phase of methanol: chloroform (2:8) and quantitative analysis using densitometry which scan spectra at maximum wavelength. The result of standardization for non-specific parameter shows moisture content $(7.33 \pm 0.52 \% \mathrm{v} / \mathrm{w})$, total ash content $(6.43 \pm 0.25 \%)$, acid insoluble ash content $(0.106 \pm 0.004 \%)$, and microbial contamination test $\left(85 \times 10^{2}\right.$ CFU/g). Results for specific parameter showed organoleptic extract (thick, dark brown color, bitter taste, no smell), with a compound naphthoquinone, coumarin, flavonoids, polyphenols and alkaloids, and the levels of total naphthoquinone $(7.43 \pm 0.28 \%)$. Henna leaf extract has met the requirements according to the standard reference for Farmakope Herbal Indonesia of the terms extract as a raw material preparation of traditional medicine.

Keywords : Extract, henna leaves (Lawsonia inermis L.), non-specific parameter, specific parameter.

\section{PENDAHULUAN}

Di Indonesia terdapat lebih dari 30.000 jenis tumbuhan dan lebih dari 1.000 jenis tumbuhan obat telah dimanfaatkan dalam industri obat tradisional sebagai jamu, obat herbal terstandar, ataupun fitofarmaka. Obat tradisional dibuat dalam bentuk ekstrak kental atau ekstrak cair yang proses pembuatannya disesuaikan dengan bahan aktif yang terkandung serta tujuan penggunaannya, dan ekstrak tersebut harus pula terstandardisasi untuk menjamin mutu dan keamanannya (Hariyati, 2005).

Beberapa kandungan golongan senyawa dalam tumbuhan yang dimanfaatkan sebagai obat diantaranya adalah flavonoid, kumarin, lawson, tanin dan saponin. Senyawa lawson sendiri mempunyai potensi tinggi sebagai antioksidan dan secara simultan dapat menghambat toksisitas oksidatif (Guha et al., 2013). Selain itu, lawson juga memiliki aktivitas antimikroba yang luas termasuk di dalamnya sebagai antibakteri, antiviral, antimikotik dan antiparasit (Babu and Subhasree, 2009). Salah satu tanaman Indonesia yang dapat 
dimanfaatkan untuk tujuan tersebut adalah daun pacar kuku (Lawsonia inermis L.). Daun pacar kuku (Lawsonia inermis L.) memiliki kandungan kimia yang bermanfaat untuk pengobatan antara lain yaitu lawson (2-hydroxy-1,4naphtoquinone), flavonoid (luteolin, apigenin dan glikosida), kumarin (esculetin, fraxetin, scopoletin), tanin dan saponin (Borade et al., 2011; Chaundary et al., 2010). Hasil penelitian Zainab (2013), ekstrak air daun pacar kuku mempunyai potensi aktivitas biologi yang tinggi, hal ini dikarenakan salah satunya adanya kandungan naftokuinon dalam ekstrak tersebut. Adapun ekstrak daun pacar kuku dengan kandungan naftokuinon memiliki potensi aktivitas biologi yang tinggi, maka untuk memperoleh ekstrak yang berkualitas perlu adanya penetapan parameter standardisasi ekstrak meliputi parameter non spesifik dan spesifik yaitu kadar air, kadar abu total, kadar abu tidak larut asam, uji cemaran mikroba, organoleptis ekstrak, uji kualitatif serta kuantitatif kandungan senyawa dalam ekstrak (Anonim, 2000; Anonim, 2008). Hasil penelitian penetapan parameter standardisasi ekstrak daun pacar kuku ini diharapkan dapat dijadikan acuan sebagai parameter standar mutu ekstrak dalam menunjang kesehatan karena belum tercantum dalam buku Materia Medika Indonesia dan Monografi Ekstrak Tumbuhan Obat.

\section{METODE PENELITIAN}

Peralatan yang digunakan dalam penelitian ini adalah inkubator, oven, timbangan analitik (AND GR 202), eksikator, krus porselin, tanur (Ney Vulcan D130), aluminium foil, kertas saring, densitometer (Camag TLC Scanner 3), alat infundasi meliputi panci infusa, penangas air, waterbath (Memmerth), termometer, corong buchner (pyrex-iwaki), penggaris, kamera. Bahan yang digunakan dalam penelitian ini adalah daun pacar kuku (Lawsonia inermis L.), standar Lawson p.a (Aldrich), media $\mathrm{MH}, \mathrm{NaCl}$ 0,9\%, methanol p.a (E-Merck), kloroform p.a (E-Merck), akuades, pereaksi $\mathrm{FeCl}_{3}$ p.a (E-Merck), pereaksi $\mathrm{AlCl}_{3}$ p.a (E-Merck), toluena p.a (E-Merck), asam klorida encer p.a (E-Merck), pereaksi Dragendrof, dan $\mathrm{KOH} \mathrm{10 \%} \mathrm{dalam} \mathrm{etanol} \mathrm{p.a} \mathrm{(E-Merck).}$ 
Jalannya Penelitian

\section{A. Determinasi Tanaman}

Identifikasi tanaman/determinasi dilakukan untuk memastikan bahan yang digunakan benar-benar daun pacar kuku (Lawsonia inermis L.). Determinasi dilakukan di Laboratorium Biologi Fakultas Matematika dan Ilmu Pengetahuan Alam (FMIPA) Universitas Ahmad Dahlan Yogyakarta dengan buku acuan Flora of Java karangan Backer and Van (1965).

B. Pengumpulan Bahan

Daun pacar kuku (Lawsonia inermis L.) diperoleh dari Celeban Baru Yogyakarta, pada bulan Oktober 2015.

C. Pembuatan Ekstrak Daun Pacar Kuku

Pembuatan ekstrak dilakukan dengan cara infundasi. Serbuk simplisia daun pacar kuku yang telah kering, ditimbang sebanyak $100 \mathrm{~g}$ dibasahi dengan akuades sebanyak $200 \mathrm{~mL}$ kemudian diinfundasi dengan menggunakan $900 \mathrm{~mL}$ akuades ke dalam panci selama 15 menit setelah mencapai suhu $90^{\circ} \mathrm{C}$, diuapkan di atas waterbath pada suhu $50^{\circ} \mathrm{C}$ hingga diperoleh ekstrak kental.

D. Parameter Organoleptis

Untuk mengetahui organoleptis dari ekstrak daun pacar kuku, digunakan panca indera untuk mendeskripsikan bentuk, bau, rasa dan warna.

\section{E. Penetapan Kadar Air}

Penetapan kadar air pada penelitian ini menggunakan cara destilasi toluen, yaitu ekstrak ditimbang sebanyak $5 \mathrm{~g}$ dan dimasukkan ke dalam labu, kemudian dimasukkan lebih kurang $200 \mathrm{~mL}$ toluen P yang sudah dijenuhkan 18-24 jam ke dalam labu dan alat dihubungkan dan dilakukan destilasi sampai adanya pemisahan antara air dan toluen.

\section{F. Penetapan Kadar Abu Total}

Kadar abu ekstrak daun pacar kuku ditetapkan dengan metode gravimetri. Ditimbang sebanyak 2 g ekstrak daun pacar kuku ke dalam krus yang telah ditimbang sebelumnya, kemudian dipijarkan bertahap hingga suhu $600 \pm 25^{\circ} \mathrm{C}$.

G. Penetapan Kadar Abu Tidak Larut Asam

Abu yang diperoleh dididihkan dengan $25 \mathrm{~mL}$ asam klorida encer selama 5 menit. Pengumpulan bagian yang tidak larut asam, disaring melalui kertas saring 
bebas abu, dicuci dengan air panas. Abu yang tersaring dan kertas saringnya dimasukkan kembali dalam krus silikat yang sama, dipijarkan secara perlahanlahan dalam krus (dengan suhu dinaikkan secara bertahap hingga $600 \pm 25^{\circ} \mathrm{C}$, kemudian ditimbang hingga bobot tetap (Anonim, 2000).

H. Uji Cemaran Mikroba dengan Metode Angka Lempeng Total

Sampel ekstrak 0,5 g dimasukkan ke dalam tabung reaksi yang telah berisi 4,5 mL NaCl 0,9\% steril (pengenceran 1:10, 1:100, 1:1000, 1:10.000 dengan $\mathrm{NaCl}$ 0,9\% steril). Dimasukkan ke dalam lemari inkubator suhu $37^{\circ} \mathrm{C}$ selama $18-24$ jam, dihitung koloni yang tumbuh.

I. Optimasi Fase Gerak

Fase diam silika gel $60 \mathrm{~F}_{254}$ terlebih dahulu dipanaskan pada suhu 105$110^{\circ} \mathrm{C}$ selama $1 \mathrm{jam}$. Ekstrak daun pacar kuku dengan konsentrasi $20 \%$ ditotolkan sebanyak $5 \mu \mathrm{L}$ pada fase diam, kemudian dielusi dengan fase gerak kloroform : metanol 8:2 (Fatmawati, 2015) dan komposisi yang kedua kloroform : metanol 7:3 (Zainab, 2013).

J. Penentuan Profil dan Uji Kromatografi Lapis Tipis

Ekstrak daun pacar kuku konsentrasi $20 \%$ ditotolkan sebanyak $\pm 5 \mu \mathrm{L}$ pada fase diam, kemudian dielusi dengan fase gerak kloroform : metanol (8:2). Plate KLT yang sudah dielusi dideteksi pada sinar UV $254 \mathrm{~nm}$ dan UV $365 \mathrm{~nm}$ kemudian dihitung Rf masing-masing. Bercak diidentifikasi dengan pereaksi semprot $\mathrm{KOH} 10 \%$ dalam etanol (naftokuinon dan kumarin), $\mathrm{FeCl}_{3}$ (fenol), $\mathrm{AlCl}_{3}$ (flavonoid), dan pereaksi Dragendrof untuk alkaloida (Harborn, 2006; Stahl, 1985).

K. Pengukuran Kadar Naftokuinon Total Secara Densitometri

1. Pembuatan Standar Lawson

Ditimbang serbuk standar lawson sebanyak 20,0 mg, kemudian dilarutkan dengan metanol p.a sampai 10,0 mL. Dibuat seri larutan kurva baku dengan pengenceran menggunakan metanol p.a hingga konsentarsi 0,$125 ; 0,25 ; 0,5 ; 0,75$ dan $1,0 \mathrm{mg} / \mathrm{mL}$. 
2. Pembuatan Sampel Larutan Uji dengan Konsentrasi $50 \mathrm{mg} / \mathrm{mL}$

Ditimbang ekstrak daun pacar kuku (Lawsonia inermis L.) sebanyak 250,0 mg dilarutkan dengan akuades hingga $5 \mathrm{~mL}$. Pembuatan sampel larutan uji dilakukan sebanyak 5 kali replikasi.

3. Kromatografi Lapis Tipis

Ditotolkan masing-masing $1 \mu \mathrm{L}$ larutan deret standar $(0,125 ; 0,25 ; 0,5$; 0,75 dan 1,0 mg/mL) dan larutan uji $5 \mu \mathrm{L}(50 \mathrm{mg} / \mathrm{mL})$ dengan 5 kali replikasi pada lempeng kromatografi lapis tipis (KLT) silika gel $60 \quad \mathrm{~F}_{254}$, kemudian dielusi dengan fase gerak metanol : kloroform (2:8).

4. Pengukuran Kadar Lawson Secara Densitometri

Bercak yang muncul pada fase diam dari larutan standar Lawson dan ekstrak sampel pada Rf yang sama, kemudian discanning dengan densitometer pada panjang gelombang serapan maksimal sehingga dapat diketahui harga $\mathrm{Rf}$ sesungguhnya, luas area dan persamaan regresi linier, dihitung kadar (\%).

\section{HASIL DAN PEMBAHASAN}

A. Determinasi Tanaman

Berdasarkan hasil determinasi dapat dipastikan bahwa tumbuhan yang digunakan adalah benar-benar tumbuhan pacar kuku (Lawsonia inermis L.).

B. Pengumpulan dan Pembuatan Simplisia

Bahan utama yang digunakan dalam penelitian ini adalah daun pacar kuku yang tua, segar, dan tidak terkena penyakit yang diperoleh dari Celeban Baru, Umbulharjo, Yogyakarta bulan Oktober 2015.

C. Hasil Pembuatan Ekstrak Daun Pacar Kuku

Proses ekstraksi pada penelitian ini menggunakan metode infundasi karena beberapa kandungan senyawa kimia daun pacar kuku bersifat polar seperti glikosida naftokinon, glikosida flavonoid dan lain-lain sehingga kandungan zat aktif yang larut dalam air tersebut akan tersari dengan baik. Penyarian dengan cara infundasi ini mudah digunakan oleh masyarakat karena pembuatan infusa ini dengan cara direbus saja. Hasil rendemen ekstrak pacar kuku tersaji pada Tabel I. 
Tabel I. Hasil rendemen ekstrak daun pacar kuku

\begin{tabular}{ccc} 
Bobot serbuk simplisia (g) & Bobot ekstrak $(\mathrm{g})$ & Rendemen $(\%)$ \\
\hline 300,04 & 65,30 & 21,76
\end{tabular}

D. Hasil Penetapan Parameter Non Spesifik Ekstrak Daun Pacar Kuku

Penetapan Parameter non spesifik ekstrak secara umum dilakukan terhadap kadar air, kadar abu total, kadar abu tidak larut asam, dan cemaran mikroba dalam ekstrak. Organoleptis ekstrak dan simplisia bertujuan sebagai pengenalan awal yang sederhana seobyektif mungkin menggunakan panca indera dengan mendiskripsikan bentuk, warna, bau, dan rasa (Anonim, 2000; Anonim 2008). Hasil parameter organoleptis ekstrak daun pacar kuku tersaji pada Tabel II.

Tabel II. Hasil penetapan parameter standarisasi non spesifik ekstrak daun pacar kuku

\begin{tabular}{ll}
\hline \multicolumn{1}{c}{ Parameter uji } & \multicolumn{1}{c}{ Hasil } \\
\hline Kadar air (\%v/b) & $7,33 \pm 0,52$ \\
Kadar abu (\%) & $6,43 \pm 0,25$ \\
Kadar abu tidak larut asam $(\%)$ & $0,106 \pm 0,004$ \\
Cemaran mikroba (CFU/g) & $8,5 \times 10^{3}$ \\
\hline
\end{tabular}

Berdasarkan hasil yang terlihat pada Tabel II, kadar air ekstrak daun pacar kuku yang diperoleh $7,33 \pm 0,52 \% \mathrm{v} / \mathrm{b}$ atau kurang dari $10 \%$ sehingga dapat disimpulkan bahwa ekstrak daun pacar kuku yang digunakan memenuhi persyaratan standar. Kadar air dalam ekstrak kurang dari 10\% dapat meminimalisir tumbuhnya jamur dan kapang serta menghasilkan daya tahan penyimpanan dan mutu ekstrak daun pacar kuku tetap baik.

Penetapan kadar abu total dapat digunakan untuk memberikan gambaran kandungan mineral ekstrak, mulai dari proses awal sampai terbentuknya ekstrak, sehingga parameter kadar abu total terkait dengan kemurnian dan kontaminasi suatu ekstrak (Anonim, 2000). Pada hasil penelitian ini diperoleh kadar abu total sebesar $6,43 \pm 0,25 \%$, artinya kandungan anorganik di dalam ekstrak masih terlalu tinggi karena melebihi kadar abu ekstrak yang baik yaitu 5\%. Tetapi hasil kadar abu ini masih lebih rendah bila dibandingkan dengan hasil penelitian Jain et al., 2010 yaitu sebesar 14,60\%. Kadar abu tidak larut asam yang diperoleh pada 
penelitian ini adalah $0,106 \pm 0,004 \%$, dapat disimpulkan bahwa tingkat kontaminasi mineral atau logam yang tidak larut asam dalam suatu ekstrak maupun simplisia masih rendah.

Hasil uji cemaran mikroba diperoleh $8,5 \times 10^{3} \mathrm{CFU} / \mathrm{g}$, hasil tersebut masih tergolong di bawah batas maksimum cemaran mikroba, yaitu syarat cemaran mikroba tidak lebih dari $10^{4} \mathrm{koloni} / \mathrm{g}$ (BPOM, 2006).

E. Hasil Penetapan Parameter Spesifik Ekstrak Daun Pacar Kuku

Penetapan parameter spesifik ekstrak daun pacar kuku dilakukan terhadap organoleptis, profil kromatografi lapis tipis untuk melihat golongan senyawa kimia dan penetapan kadar naftokinon yang terdapat dalam ekstrak.

F. Hasil Uji Organoleptis Ekstrak

Uji organoleptis ekstrak yang dilakukan meliputi bentuk, warna, bau dan rasa. Uji ini dilakukan agar diperoleh gambaran awal dari esktrak yang dihasilkan. Hasil uji organoleptis ekstrak dapat dilihat pada Tabel III.

Tabel III. Hasil uji organoleptis ekstrak daun pacar kuku

\begin{tabular}{|c|c|}
\hline Parameter uji & Hasil \\
\hline \multicolumn{2}{|l|}{ Organoleptis ekstrak : } \\
\hline a. Bentuk & Kental \\
\hline b. Warna & Coklat tua \\
\hline c. $\mathrm{Bau}$ & Bau khas daun pacar kuku \\
\hline d. Rasa & Agak pahit \\
\hline
\end{tabular}

G. Hasil Penentuan Profil dan Uji Kromatografi Lapis Tipis

Uji identifikasi dilakukan untuk mengetahui golongan senyawa yang terkandung dalam ekstrak daun pacar kuku (Lawsonia inermis L.) dan hasil identifikasi naftokinon, polifenol, alkaloid, kumarin dan flavonoid tersaji pada Tabel IV, V, VI, VII dan VIII.

Hasil data pada Tabel IV dapat dilihat bahwa terdapat 1 bercak standar lawson dengan $\operatorname{Rf} 0,38$, dan 6 bercak sampel dengan $\operatorname{Rf} 0,10 ; 0,21 ; 0,38 ; 0,53$; 0,69 dan 0,81. Bercak sampel no 1,2, dan 3 dengan $\operatorname{Rf} 0,10 ; 0,21 ; 0,38$ menunjukkan ciri bercak naftokinon karena terjadi pemadaman di bawah sinar UV $254 \mathrm{~nm}$, berfluoresensi merah kecoklatan pada UV $365 \mathrm{~nm}$ dan bila disemprot dengan $\mathrm{KOH} 10 \%$ terdapat bercak berwarna orange atau coklat kemerahan 
(Wagner and Bladt, 1996). Berdasarkan hal tersebut maka dapat disimpulkan bahwa di dalam ekstrak daun pacar kuku memiliki kandungan naftokuinon.

Tabel IV. Hasil identifikasi naftokuinon secara KLT

\begin{tabular}{|c|c|c|c|c|c|c|}
\hline \multirow[b]{2}{*}{ Totolan } & \multicolumn{5}{|c|}{ Deteksi } & \multirow{2}{*}{$\begin{array}{l}\text { Keberadaan } \\
\text { naftokuinon }\end{array}$} \\
\hline & $\mathbf{R f}$ & UV 254 & $\begin{array}{l}\text { UV } \\
365\end{array}$ & $\begin{array}{c}\text { UV } \\
365+\mathrm{KOH} \\
10 \%\end{array}$ & $\begin{array}{c}\text { Visibel } \\
+\mathrm{KOH} \\
10 \%\end{array}$ & \\
\hline \multirow[t]{6}{*}{ Ekstrak } & 0,10 & Pemadaman & Biru & $\begin{array}{c}\text { Merah } \\
\text { kecoklatan }\end{array}$ & $\begin{array}{l}\text { Kuning } \\
\text { orange }\end{array}$ & + \\
\hline & 0,21 & Pemadaman & Biru & $\begin{array}{c}\text { Merah } \\
\text { kecoklatan }\end{array}$ & $\begin{array}{l}\text { Kuning } \\
\text { orange }\end{array}$ & + \\
\hline & 0,38 & Pemadaman & Biru & $\begin{array}{c}\text { Merah } \\
\text { kecoklatan }\end{array}$ & $\begin{array}{l}\text { Kuning } \\
\text { orange }\end{array}$ & + \\
\hline & 0,53 & Pemadaman & Kuning & Biru & Kuning & - \\
\hline & 0,69 & Pemadaman & Biru & Biru & Kuning & - \\
\hline & 0,81 & Pemadaman & Biru & Biru & Kuning & - \\
\hline Naftokuinon & 0,38 & Pemadaman & Biru & $\begin{array}{c}\text { Merah } \\
\text { kecoklatan }\end{array}$ & $\begin{array}{l}\text { Kuning } \\
\text { orange }\end{array}$ & + \\
\hline
\end{tabular}

Tabel V. Hasil identifikasi polifenol secara KLT

\begin{tabular}{|c|c|c|c|c|c|}
\hline \multirow{2}{*}{ Totolan } & \multicolumn{4}{|c|}{ Deteksi } & \multirow{2}{*}{$\begin{array}{c}\text { Keberadaan } \\
\text { polifenol }\end{array}$} \\
\hline & $\mathbf{R f}$ & UV 254 & UV 365 & $\begin{array}{c}\text { Visibel + } \\
\mathrm{FeCl}_{3}\end{array}$ & \\
\hline \multirow[t]{6}{*}{ Ekstrak } & 0,13 & Pemadaman & Biru & $\begin{array}{c}\text { Hijau } \\
\text { kehitaman }\end{array}$ & + \\
\hline & 0,23 & Pemadaman & Biru & $\begin{array}{c}\text { Hijau } \\
\text { kehitaman }\end{array}$ & + \\
\hline & 0,38 & Pemadaman & Biru & $\begin{array}{c}\text { Hijau } \\
\text { kehitaman }\end{array}$ & + \\
\hline & 0,50 & Pemadaman & Kuning & $\begin{array}{c}\text { Hijau } \\
\text { kehitaman }\end{array}$ & + \\
\hline & 0,69 & Pemadaman & Biru & $\begin{array}{l}\text { Hijau } \\
\text { kehitaman }\end{array}$ & + \\
\hline & 0,81 & Pemadaman & Biru & $\begin{array}{l}\text { Hijau } \\
\text { kehitaman }\end{array}$ & + \\
\hline Quersetin & 0,51 & Pemadaman & Kuning & $\begin{array}{c}\text { Hijau } \\
\text { kehitaman }\end{array}$ & + \\
\hline
\end{tabular}

Hasil data Tabel V dapat dilihat bahwa terdapat 1 bercak standar dengan Rf 0,51, dan 6 bercak sampel dengan $\operatorname{Rf} 0,13 ; 0,23 ; 0,38 ; 0,50 ; 0,69$ dan 0,81 menunjukkan pemadaman di bawah sinar UV $254 \mathrm{~nm}$, berfluoresensi biru pada UV $365 \mathrm{~nm}$, bila disemprot dengan $\mathrm{FeCl}_{3}$ terdapat bercak berwarna hijau 
kehitaman pada sinar tampak. Berdasarkan hal tersebut dapat disimpulkan bahwa didalam ekstrak daun pacar kuku memiliki kandungan polifenol. Harga Rf menunjukkan bahwa terdapat senyawa polifenol pada uji KLT. Harga Rf ekstrak yang mendekati standar yaitu 0,50, jadi dapat disimpulkan bahwa di dalam ekstrak daun pacar kuku mengandung polifenol.

Tabel VI. Hasil identifikasi alkaloid secara KLT

\begin{tabular}{|c|c|c|c|c|c|}
\hline \multirow{2}{*}{ Totolan } & & \multicolumn{3}{|c|}{ Deteksi } & \multirow{2}{*}{$\begin{array}{l}\text { Keberadaan } \\
\text { alkaloid }\end{array}$} \\
\hline & $\mathbf{R f}$ & UV 254 & UV 365 & $\begin{array}{c}\text { Visibel + } \\
\text { Dragendrof }\end{array}$ & \\
\hline \multirow{6}{*}{ Ekstrak } & 0,13 & Pemadaman & Biru & Coklat & - \\
\hline & 0,24 & Pemadaman & Biru & Coklat & - \\
\hline & 0,39 & Pemadaman & Biru & Coklat & - \\
\hline & 0,53 & Pemadaman & Kuning & Coklat & - \\
\hline & 0,69 & Pemadaman & Biru & Kuning & - \\
\hline & 0,84 & Pemadaman & Biru & Orange & + \\
\hline Piperin & 0,84 & Pemadaman & Biru & Orange & + \\
\hline
\end{tabular}

Pada Tabel VI terdapat 1 bercak standar piperin (Rf 0,84) dan 6 bercak sampel (Rf 0,$13 ; 0,24 ; 0,39 ; 0,53 ; 0,69 ; 0,84$. Pada bercak sampel ekstrak daun pacar kuku Rf 0,84 menunjukkan pemadaman di bawah sinar UV $254 \mathrm{~nm}$, berwarna orange kecoklatan dan kuning muda pada sinar visibel serta berfluoresensi biru di bawah sinar UV $365 \mathrm{~nm}$ yang karakteristiknya sama dengan standar piperin. Berdasarkan hal tersebut maka dapat disimpulkan bahwa di dalam ekstrak daun pacar kuku terdapat kandungan alkaloid.

Hasil data Tabel VII bahwa terdapat 1 bercak standar dengan Rf 0,83, dan 6 bercak sampel dengan $\operatorname{Rf} 0,13 ; 0,24 ; 0,39 ; 0,54 ; 0,69$; dan 0,81. Pada bercak sampel ekstrak daun pacar kuku menunjukkan warna kuning kecoklatan pada sinar tampak dan pemadaman di bawah sinar UV $254 \mathrm{~nm}$ dan bercak nomor 6 (Rf 0,81) menunjukkan fluoresensi biru intensif setelah disemprot $\mathrm{KOH} 10 \%$ di bawah sinar UV $365 \mathrm{~nm}$. Berdasarkan hal tersebut dapat disimpulkankan bahwa di dalam ekstrak daun pacar kuku memiliki kandungan kumarin. Harga Rf ekstrak mendekati standar yaitu 0,81, jadi dapat disimpulkan bahwa ekstrak daun pacar kuku mengandung kumarin. 
Tabel VIII. Hasil identifikasi kumarin secara KLT

\begin{tabular}{|c|c|c|c|c|c|c|}
\hline \multirow[b]{2}{*}{ Totolan } & \multicolumn{5}{|c|}{ Deteksi } & \multirow{2}{*}{$\begin{array}{l}\text { Keberadaan } \\
\text { kumarin }\end{array}$} \\
\hline & $\mathbf{R f}$ & UV 254 & UV 365 & $\begin{array}{c}\mathrm{UV} \\
365+\mathrm{FeCl}_{3}\end{array}$ & $\begin{array}{c}\text { Visibel+ } \\
\text { KOH 10\% }\end{array}$ & \\
\hline \multirow[t]{6}{*}{ Ekstrak } & 0,13 & Padam & $\begin{array}{c}\text { Fluoresensi } \\
\text { Biru }\end{array}$ & Biru & Kuning & - \\
\hline & 0,24 & Padam & $\begin{array}{c}\text { Fluoresensi } \\
\text { Biru }\end{array}$ & Biru & Kuning & - \\
\hline & 0,39 & Padam & $\begin{array}{c}\text { Fluoresensi } \\
\text { Biru }\end{array}$ & Biru & Kuning & - \\
\hline & 0,54 & Padam & $\begin{array}{c}\text { Fluoresensi } \\
\text { Biru }\end{array}$ & Biru & Kuning & - \\
\hline & 0,69 & Padam & $\begin{array}{c}\text { Fluoresensi } \\
\text { Biru }\end{array}$ & Biru & Kuning & - \\
\hline & 0,81 & Padam & $\begin{array}{c}\text { Fluoresensi } \\
\text { Biru }\end{array}$ & $\begin{array}{l}\text { Fluoresensi } \\
\text { biru intensif }\end{array}$ & Kuning & + \\
\hline Kumarin & 0,83 & Padam & $\begin{array}{c}\text { Fluoresensi } \\
\text { Biru }\end{array}$ & $\begin{array}{l}\text { Fluoresensi } \\
\text { biru intensif }\end{array}$ & Kuning & + \\
\hline
\end{tabular}

Tabel VIII. Hasil identifikasi flavonoid secara KLT

\begin{tabular}{|c|c|c|c|c|c|}
\hline \multirow[b]{2}{*}{ Totolan } & \multicolumn{4}{|c|}{ Deteksi } & \multirow{2}{*}{$\begin{array}{c}\text { Keberadaan } \\
\text { flavonoid }\end{array}$} \\
\hline & $\mathbf{R f}$ & UV 254 & UV 365 & $\begin{array}{c}\text { Visibel + } \\
\mathrm{AlCl}_{3}\end{array}$ & \\
\hline \multirow[t]{6}{*}{ Ekstrak } & 0,13 & Pemadaman & Biru & $\begin{array}{c}\text { Kuning } \\
\text { orange }\end{array}$ & - \\
\hline & 0,23 & Pemadaman & Biru & $\begin{array}{l}\text { Kuning } \\
\text { orange }\end{array}$ & - \\
\hline & 0,39 & Pemadaman & Biru & $\begin{array}{l}\text { Kuning } \\
\text { orange }\end{array}$ & - \\
\hline & 0,51 & Pemadaman & Kuning & Kuning & + \\
\hline & 0,69 & Pemadaman & Biru & - & - \\
\hline & 0,81 & Pemadaman & Biru & - & - \\
\hline Quersetin & 0,51 & Pemadaman & Kuning & Kuning & + \\
\hline
\end{tabular}

Hasil data Tabel VIII terdapat 1 bercak standar dengan Rf 0,51, dan 6 bercak sampel dengan Rf 0,$13 ; 0,23 ; 0,39 ; 0,51 ; 0,69 ;$ dan 0,81 . Bercak no 4 (Rf 0,51) menunjukkan pemadaman di bawah sinar UV $254 \mathrm{~nm}$ dengan latar belakang hijau, di bawah sinar UV $365 \mathrm{~nm}$ berfluoresensi kuning dan setelah disemprot dengan $\mathrm{AlCl}_{3}$ berwarna kuning. Berdasarkan hal tersebut maka dapat disimpulkan ekstrak daun pacar kuku memiliki kandungan flavonoid. 
Berdasarkan hasil uji KLT menunjukkan bahwa dalam ekstrak daun pacar kuku mengandung naftokuinon, kumarin, flavonoid, polifenol, dan alkaloid, sedangkan hasil penelitian Jubaidah (2006) menyebutkan pada hasil hidrolisis infusa daun pacar kuku mengandung senyawa golongan naftokinon dan flavonoid.

\section{H. Hasil Pengukuran Kadar Naftokuinon Total secara Densitometri}

Data yang diperoleh yaitu panjang gelombang absorbansi maksimum untuk standar lawson adalah $268 \mathrm{~nm}$ sedangkan untuk panjang gelombang absorbansi maksimum untuk sampel ekstrak daun pacar kuku adalah $285 \mathrm{~nm}$ pada Rf sampel 0,38 dan Rf standar 0,39. Range panjang gelombang absorbansi maksimum untuk senyawa naftokuinon muncul pada 264-340 nm (Rene, 2005). Hal tersebut menunjukkan bahwa bercak sampel dengan Rf 0,38 adalah senyawa lawson. Data luas area kromatogram tersaji pada Tabel IX.

Tabel IX. Data luas area kromatogram untuk kurva baku

\begin{tabular}{ccc}
\hline $\begin{array}{c}\text { Konsentrasi } \\
(\mathbf{m g} / \mathbf{m L})\end{array}$ & $\begin{array}{c}\text { Luas Area } \\
\text { Kromatogram }(\mathbf{V})\end{array}$ & Persamaan garis \\
\hline 0,125 & 3,2201 & \\
0,250 & 4,4792 & $\mathrm{y}=\mathrm{bx}+\mathrm{a}$ \\
0,500 & 8,4343 & $\mathrm{R}=0,9816$ \\
0,750 & 9,5271 & $\mathrm{y}=12,6657 \mathrm{x}+14,6296$ \\
1,000 & 14,9016 & \\
\hline
\end{tabular}

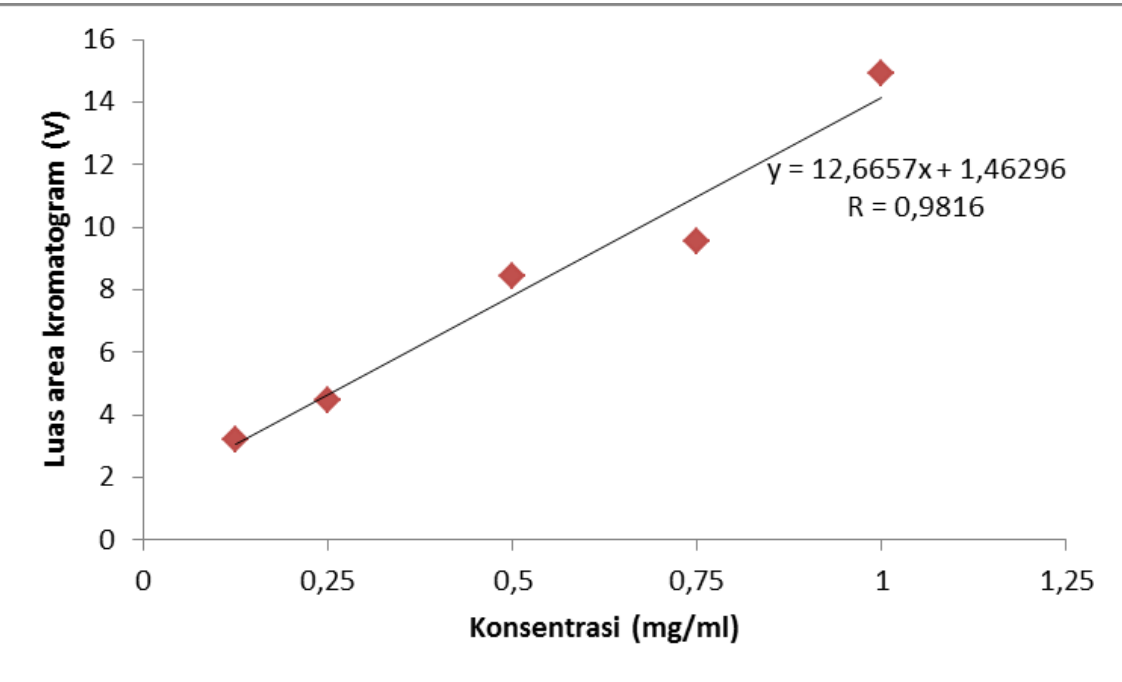

Gambar 1. Persamaan regresi linier konsentrasi standar dan absorbansi 
Berdasarkan teori untuk $\mathrm{n}=5$ dengan taraf kepercayaan 95\% maka harga $r_{\text {tabel }}=0,8783$, karena $r_{\text {hitung }} 0,9816>r_{\text {tabel }} 0,8783$ maka ada korelasi atau hubungan antara konsentrasi dengan absorbansi. Data pada Tabel X menunjukkan bahwa kadar rata-rata naftokuinon ekstrak daun pacar kuku yaitu 7,43\%. Pada penelitian pendahuluan oleh Zainab (2010) diperoleh kadar naftokuinon serbuk simplisia daun pacar kuku sebesar 1,36\% dengan metode maserasi menggunakan air. Perbedaan kadar naftokuinon yang diperoleh tersebut dapat disebabkan karena metode ekstraksi yang digunakan berbeda, dalam penelitian Zainab (2010) proses ekstraksi yang digunakan menggunakan air dingin, sedangkan dalam penelitian ini digunakan air panas, sehingga naftokuinon lebih banyak terekstrak dengan metode infundasi.

Tabel X. Data luas area kromatogram sampel dan kadar

\begin{tabular}{cccc}
\hline Replikasi & $\begin{array}{c}\text { Berat ekstrak } \\
\text { (gram) }\end{array}$ & $\begin{array}{c}\text { Luas Area } \\
\text { Kromatogram }(\mathbf{V})\end{array}$ & $\begin{array}{c}\text { Kadar naftokuinon } \\
\mathbf{\%}(\mathbf{b} / \mathbf{b})\end{array}$ \\
\hline 1 & 0,250 & 10,8679 & 7,43 \\
2 & 0,250 & 11,0896 & 7,60 \\
3 & 0,250 & 11,0365 & 7,56 \\
4 & 0,250 & 11,1865 & 7,68 \\
5 & 0,250 & 10,2012 & 6,90 \\
& $\bar{X}(\%)$ & & 7,43 \\
& CV $(\%)$ & & 4,20 \\
& SD & & 0,31 \\
& LE & & 0,28 \\
\hline
\end{tabular}

\section{KESIMPULAN}

Parameter non spesifik ekstrak daun pacar kuku meliputi kadar air $(7,33 \pm 0,52 \% \mathrm{v} / \mathrm{b})$, kadar abu total $(6,43 \pm 0,25 \%)$, kadar abu tidak larut asam $(0,106 \pm 0,004 \%)$, dan uji cemaran mikroba $\left(8,5 \times 10^{3} \mathrm{CFU} / \mathrm{g}\right)$. Parameter spesifik ekstrak daun pacar kuku secara organoletik ekstrak adalah ekstrak kental yang berwarna coklat tua, berasa agak pahit dan bau khas daun pacar kuku. Ekstrak daun pacar kuku mengandung senyawa naftokuinon, kumarin, flavonoid, polifenol, dan alkaloid. Kadar naftokuinon ekstrak daun pacar kuku sebesar $7,43 \pm 0,29 \%$. 


\section{UCAPAN TERIMA KASIH}

Penulis mengucapkan banyak terimakasih kepada LPP UAD yang telah memberikan dukungan dana penelitian ini. Penulis juga mengucapkan terima kasih kepada pihak-pihak yang memberikan dukungan hingga penelitian ini dapat terselesaikan.

\section{DAFTAR PUSTAKA}

Anonim, 2000, Parameter Standar Umum Ekstrak Tumbuhan Obat, Edisi I, Departemen Kesehatan Republik Indonesia, Jakarta.

Babu, D.P. and Subhasree R.S., 2009, Antimicrobial Activities of Lawsonia inermis, Academic Journal of Plant Sciences, 2 (4): 231-232.

Backer, C.A. and Van Den Brink Jr., R.C.B., 1965, Flora of Java, Published under The Auspices of The Rijksherbarium, Leyden, 1: 251-256.

BPOM, 2006, Monografi Ekstrak Tumbuhan Obat Vol. 2, BPOM, Jakarta.

Borade, A.S., Babasaheb, N., Kale and Shete, R.R.V., 2011, A Phytopharmacological review on Lawsonia inermis (Linn.), International Journal of Pharmacy and Life Scieces, 2 (1): 536-541.

Chaundhary, G., Goyal, S., and Poonia, P., 2010, Lawsonia inermis Linnaeus: A Phytopharmacological Review, International Journal of Pharmaceutical Sciences and Drug Research, 2 (2): 91-98.

Fatmawati A., 2015, Aktivitas Antioksidan Ekstrak Etanol dan Fraksi Etil Asetat Daun Pacar Kuku (Lawsonia inermis L.) dengan Metode Fosfomolibdat, Skripsi, Fakultas Farmasi Universitas Ahmad Dahlan, Yogyakarta.

Guha, G., Rajkumar, V., and Mathew, L., 2009, Antioxidant Activity of Lawsonia inermis Extract Inhibits Cromium (VI) Induced Cellular and DNA Toxicity, $e C A M$.

Harborne, J.B., 2006, Metode Fitokimia Edisi ke-2, Terjemahan Kosasih Padmawinata dan Iwang Soediro, Bandung : Penerbit ITB.

Hariyati, S., 2005, Standardisasi Ekstrak Tumbuhan Obat Indonesia, Salah Satu Tahapan Penting dalam Pengembangan Obat Asli Indonesia, Info POM, 6 (4): 1-5. 
Jain, V.C., Shah, D.P., Sonani, N.G., Dhakara, S. and Patel, N.M., 2010, Pharmacognostical and Preliminary Phytochemical Investigation of Lawsonia inermis L. Leaf, Rom.J.Biol-Plant Biol., Bucharest, 55 (2): 127-133.

Jubaidah, S., 2006, Uji Aktivitas Antibakteri Infusa Daun Pacar Kuku (Lawsonia inermis L.) terhadap Bakteri Staphylococcus aureus dan Escerichia coli Secara In Vitro serta Profil Kromatogramnya, Skripsi, Fakultas Farmasi Universitas Ahmad Dahlan, Yogyakarta.

Rene, 2005, Enviromental Organic Chemistry, Cetakan Kedua, Wiley, 620.

Stahl, E., 1985, Analisis Obat secara Kromatografi dan Mikroskopi, Terjemahan Kosasih Padmawinata dan Iwang Soediro), Bandung: ITB Press.

Wagner, H. and Bladt, S., 1996, Plant Drug Analysis A Thin Layer Chromatography Atlas, $2^{\text {nd }}$ ed., Spinger-Verlag Berlin Heidelberg, 6, 54, 126, 196, 275.

Zainab, 2010, Pengaruh Konsentrasi Etanol sebagai Pelarut Pengekstraksi terhadap Kadar Naftokinon dalam Ekstrak Daun Pacar Kuku (Lawsonia inermis L.), Pharmaciana, 3 (2): 63-68.

Zainab, 2013, TLC Screening for Antioxidant Activity of Henna (Lawsonia inermis L.) Leaf Extract, International Proceeding of SMCCR. 